\title{
Involvement of ZmMPK14 in Plant Defense Revealed by Comparative Expression Analysis
}

\section{ZmMPK14'ün Bitki Savunmasında Görev Aldığının Mukayeseli Ekspresyon Analiziyle Belirlenmesi}

\begin{abstract}
Mehmet Ali Südüpak ${ }^{1^{*}}$
Geliş / Received: 26/04/2021

Revize / Revised: 07/09/2021

Kabul / Accepted: 19/09/2021

ABSTRACT

Mitogen-Activated Protein Kinases (MAPKs) function in signaling pathways as modules cascading between stimulus activated sensors and response mechanisms.ZmMAPK14, a group C final MAPK of this cascade was identified as a differentially expressed message in cDNA-AFLP studies of both susceptible and resistant genotypes, where a gradual induction was displayed in the resistant genotype while a clear repression occurred in the susceptible genotype in response to Puccinia sorghi $(P s)$ inoculation. RT-qPCR verification studies, however, did not reveal the same pattern of expression in that both displayed inductions at different levels. $P s$ inoculation induced a limited expression increase fluctuating between 1.5 and 2.5-fold in the susceptible genotype while a dramatic upregulation starting at $12 \mathrm{~h}$ with a 149-fold and gradually increasing to a maximum level of 477 folds at $72 \mathrm{~h}$ in resistant genotype was observed. To obtain further evidence about its role in plant defense, ZmMapk14 expression in response to applications of chitin, Salicylic Acid (SA) and $\mathrm{H}_{2} \mathrm{O}_{2}$ at six time points covering a 0-24 h interval were studied in both genotypes. All treatments induced ZmMapk14 expression in the resistant genotype significantly at different levels while the expressional changes in the susceptible were more complex and limited similar to the Ps inoculation levels in the susceptible. Overall, the results show that ZmMAPK14 display differential expression in resistant and susceptible genotypes in response to $P s$ inoculation and applied defense compounds, and it presumably functions in plant defense to $P S$.
\end{abstract}

\section{Keywords- ZmMAPK14, Plant Defense, SA, Chitin, $\mathrm{H}_{2} \mathrm{O}_{2}$}

\section{$\overline{\mathbf{O Z Z}}$}

Mitojenle-Aktive olan Protein Kinazlar (MAPKs) stimulusla aktive olan sensörlerle yanıt mekanizmaları arasında sinyal iletiminde kaskadlar halinde fonksiyonel olan moleküllerdir. Bu kaskadların son basamağında bir grup $\mathrm{C}$ MAPK olan ZmMAPK14 duyarlı ve dirençli genotipi cDNA-AFLP çalışmalarında diferansiyel ekspresyon gösteren bir mesaj olarak tanımlanmıştır: Puccinia sorghi $(P s)$ inokülasyonuyla dirençli genotipte göreceli bir indüksiyon görülürken, duyarlı genotipte belirgin bir represyon tespit edilmiştir. RT-qPCR çalışmaları diğer taraftan $P s$ inokülasyonuyla her iki genotipte farklı düzeylerde indüksiyon olduğunu göstermiştir: Duyarlı genotipte kontrole göre 1.5- 2.5 kat arasında değişim gösteren bir ekspresyon artışı görülürken dirençli genotipte 12. h'de 149 kat ile başlayan ve 72. h'de 477 kat tepe değerine ulaşılan dramatik göreceli bir artış gözlenmiştir. Söz konusu MAP Kinazın bitki savunmasında rolüyle ilgili daha somut bulgular elde etmek için, kitin, Salisilik Asit (SA) ve $\mathrm{H}_{2} \mathrm{O}_{2}$ uygulamalarıyla ZmMapk14 ekspresyonunda değişim her iki genotipte 0-24 aralığını kapsayan altı örnekleme noktasında çalışılmıştır. Tüm uygulamalar dirençli genotipte istatistiki önemli indüksiyonlar ortaya çıkarırken, duyarlı genoptipte ekspresyon değişimleri $P$ s uygulamasındakine benzer düzede kompleks ve sınırlı

1*Sorumlu yazar iletişim: msudupak@hotmail.com (https://orcid.org/0000-0001-9439-0916)

Fen-Edebiyat Fakültesi Biyoloji Bölümü, Bozok Üniversitesi, 66100, Yozgat 
olarak tespit edilmiştir. Sonuçlar, ZmMAPK14 ekspresyonunun gerçekleştirilen uygulamalarla değişim gösterdiğini ve $P s^{\prime}$ 'e karşı bitki savunmasında fonksiyonel olduğunu göstermektedir.

\section{Anahtar Kelimeler-ZmMAPK14, Bitki Savunması, $\mathrm{SA}$, Kitin, $\mathrm{H}_{2} \mathrm{O}_{2}$}

\section{I.INTRODUCTION}

MAPKs, as constituents of the many signal transduction pathways, function between stimulus activated sensors and target molecules, which appear to regulate many aspects of the plant life from growth and development to biotic and abiotic stress responses [1,2]. Plant MAPK cascades formed by the members of three or more protein kinase sub-families (MAP4K, MAP3K, MAP2K and MAPK) are linearly organized and sequentially activated via phosphorylation in relaying signal to downstream target molecules $[3,4]$.

A number of studies have been conducted in maize to identify MAP Kinase genes in genome-wide: Kong et al. [5,6] concluded that there are 74 MAP3Ks and 9 MAPKKs in the genome. Wei et al. [7], on the other hand, detected 9 MAP4Ks, 84 MAP3Ks, 18 MAPKKs and 19 MAPKs. Based on sequence and structural homology to the Arabidopsis and rice MAPKs, 19 maize MAPKs have been classified into four major clades corresponding to the groups, A, B, C and D in Arabidopsis [7]. According to the activation loop sequence motif, MAPKs can be either of two subtypes, as TEY or TDY, both of which are phosphorylated at threonine and tyrosine residues by MAP2Ks. Maize group A, B, C MAPKs are TEY type containing 4, 2 and 2 identified members respectively while the group D comprises 11 TDY type MAPKs [8,9]. In identification and naming maize MAPKs, different similarities and designations have been reported: Liu et. al. [8] designated the members of group C MAPKs as ZmMAPK1 and ZmMAKP2, whereas Wei [7] named them as ZmMAPK8 and ZmMAPK9 while Sun et. al. [10] identified them as ZmMAPK2 and ZmMAPK8. In a more comprehensive study, Mohanta et. al. [9] found them closer to the AtMAPK7 and AtMAPK14 and designated as ZmMAPK7 and ZmMAPK14 (used in this report as well) respectively. ZmMAPK14 encodes a 370 aa polypeptide with the size of $42.46 \mathrm{kDa}$.

MAPK cascades, regarded as central signaling modules in plant immunity and regulation, have been shown to participate in both Pattern-Triggered Immunity (PTI) and Effector-Triggered Immunity (ETI) [4,11-14]. One of the early events was demonstrated to be the MAPKs activation occurring transiently in PTI after a pathogen/microbe-associated pattern (P/MAMPs) recognition and during ETI in a sustained manner $[14,15]$. Identified MAPK cascades have been shown to function in multiple defense responses ranging from synthesis of reactive oxygen species (ROS), plant stress/defense hormones and phytoalexins to cell wall strengthening, defense gene activation and hypersensitive reaction (HR) induction $[4,15]$. To counteract these defense responses and promote virulence, pathogens are shown to employ effectors to block MAPKs and preceding signaling components [13,15-18]. Arabidopsis MAPK3/6 (Group A) and MAPK4 (Group B) and their identified cascades are regarded as the hallmark of plant immunity [2,13]. Similarly, the group C orthologues i.e., OsMAPK3 in rice [19], GhMAPK2 in cotton [20,21] and a number of other MAPKs have been reported to participate in plant defense signaling [2]. Two well-characterized MAPK cascades are known to be activated upon perception of PAMPs in Arabidopsis: One is formed by MAPKKK3/5, MAPKK4/5 and MAPK3/6 and functions downstream of Pattern Recognition Receptors (PRRs) of FLS2 and EFR [22]. The other one consists of MAPKKK1, MAPKK1/2 and MAPK4 [23]. Several Pseudomonas effectors are known to target the components of both cascades in suppressing PTI and regulating plant immunity: HopAI1 suppresses PAMP induced gene expression and callose deposition by directly interacting with MAPK3 and MAPK6 while HopF2 appears to target MAPKKs to inhibit flg22 induced MAPK activation. As an effector, HopAI1 activates SUMM2 R protein mediated ETI by inhibiting kinase activity of MAPK4 in phosphorylation of CRCK3 [13].

Although plant MAPK cascades are regulated via posttranslational modifications, transcriptional modulations of MAP kinase genes are also frequently observed [24-26], indicating that initial production and turnover compensation of signaling components along with the expressional dynamics are presumably important in regulation and signal transduction. Expressional modulations of MAPKs in response to pathogen infections and applications of defense signaling molecules are frequently reported in many publications $[7,19,20,27,28]$. One of the well-studied MAPK genes, AtMAPK3 (orthologues in other plant species) is rapidly induced in Arabidopsis seedlings upon treatment with chitin and pathogens [4,29]. Similarly, OsMAPK3 [19] and GhMAPK2 [20] are also induced in response to pathogen/pest challenges and applications of defense hormones (SA and JA) and defenserelated compounds such as ethylene and $\mathrm{H}_{2} \mathrm{O}_{2}$. A maize orthologue of these MAPKs, ZmMAPK14 was identified as expressional modulation showing cDNA-AFLP tag in a previous study in that it displayed a marked repression 


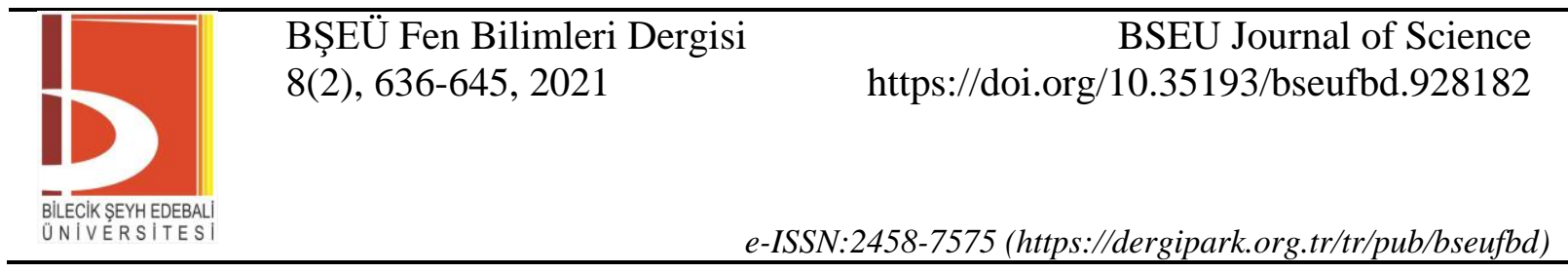

in samples of susceptible genotype and gradual induction in samples of the resistant genotype [30]. Present study was conducted to verify a previous cDNA-AFLP study observations and to obtain further evidence about its role in plant defense. Results of the RT-qPCR studies carried out to examine the expressional modulations induced in both susceptible and resistant genotypes by $P$. sorghi inoculations and the individual applications of defense inducing compounds, chitin, $\mathrm{H}_{2} \mathrm{O}_{2}$ and $\mathrm{SA}$ are reported here.

\section{MATERIALS AND METHODS}

\section{A. Biological materials, growth conditions and treatments}

P. sorghi isolate T09 and two maize lines, A188 inbred and Rpl-G, which are susceptible and resistant to T09 respectively, were used as biological materials in the study. Both A188 and RpI-G seedlings were grown and maintained at $24-27^{\circ} \mathrm{C}$ with a $16 / 8 \mathrm{~h}$ photoperiod in rust free clean chambers before the rust challenge and chemical treatments. Healthy fully-grown seven-day old seedlings were arranged in parallel as control and treatment groups. In rust treatment experiments, control group of both resistant and susceptible genotypes were rubbed with $\mathrm{ddH}_{2} \mathrm{O}$ while treatment groups of both genotypes were inoculated with freshly collected urediniospores by rubbing $\mathrm{ddH}_{2} \mathrm{O}$-wetted fingers as in control groups. In chemical treatment experiments, plant materials were also prepared in the same way in that applications were carried out by spraying onto the leaves. Treatments were carried out by spraying individually $10 \mathrm{mM}$ solutions of either $\mathrm{H}_{2} \mathrm{O}_{2}$, SA or $5 \mathrm{mg} / \mathrm{ml}$ sonicated shrimp shell chitin to their respective seedling set while sterile $\mathrm{dH}_{2} \mathrm{O}$ (treatment solvent) was sprayed to the control plants of each treatment. Following rust inoculation, both control and treatment plants were incubated overnight (in dark) at $24{ }^{\circ} \mathrm{C}$ in mist chambers with $95 \%<$ humidity and subsequently transferred to a room with a $16 / 8 \mathrm{~h}$ (day/night) photoperiod at $24-27^{\circ} \mathrm{C}$. Each experiment was conducted as three biological replicates along with their controls. Control and treatment leaf tissue samples were collected in parallel from both control and treatment plants at each time point as 0 (control), 6, 12, 24, 48, 72 and 96 post-application hours in rust experiments while chemical treatment leaf tissues were sampled in the same way at 0 (control), 1, 2, 4, 6 and $24 \mathrm{~h}$ of post-application. In each sampling event of all experimental groups, $\sim 7 \mathrm{~cm}$ segment (extending from tip to base) of the second leaf (which is $\sim 0.1 \mathrm{~g}$ ) was taken. Samples were immediately placed into sterile $1.5 \mathrm{ml}$ eppendorf tubes and frozen in $\mathrm{N}_{2(\mathrm{~L})}$, stored in $\mathrm{N}_{2(\mathrm{~L})}$ until grinding and addition of RNA extraction buffer.

\section{B. RNA isolation and RT-qPCR}

Total RNAs were isolated from the frozen seedling leaf samples as two biological replicates using RNAzol Reagent (MRC, U.S.A.) as described in Südüpak [30].Nucleic acid quantity and quality measurements were made spectrophotometrically using the ACTGene nanodrop and average yield was computed as $~ 40-60$ $\mu \mathrm{g} / 100 \mathrm{mg}$ leaf tissue with $\mathrm{A}_{260} / \mathrm{A}_{280}$ ratios between 1.9-2 and $\mathrm{A}_{260} / \mathrm{A}_{230}$ ratios between 2-2.3. From each sample, $2 \mu \mathrm{g}$ total RNA was first treated with RNase free DNase I (Thermo-Fermentas) by incubating at $37{ }^{\circ} \mathrm{C}$ for $30 \mathrm{~min}$ to eliminate gDNA contamination. Following treatment, $1 \mu \mathrm{l} 25 \mathrm{mM}$ EDTA was la added to each reaction to prevent $\mathrm{Mg}^{2+}$ catalyzed RNA hydrolysis during the DNase inactivation incubation, which was carried out at $65^{\circ} \mathrm{C}$ for $10 \mathrm{~min}$. Subsequently, prepared RNAs were reverse transcribed into cDNAs using RevertAid ${ }^{\mathrm{TM}} \mathrm{H}^{-}$reverse transcriptase (Thermo-Fermentas) and an oligo-d $\mathrm{T}_{11}$ primer together with the gene specific primer pair for $18 \mathrm{~S}$ rRNA in $30 \mu \mathrm{l}$ reaction volumes. Following reverse transcription, mixtures were subjected to $94^{\circ} \mathrm{C}$ for 5 min to inactivate enzymes and $5 \mathrm{x}$ diluted aliquots were stored at $-20^{\circ} \mathrm{C}$.

Primers used in the study were designed using Primer3plus (sourceforge.net/projects/primer3). Output primers pair list were, then, examined in the analysis utilities of Primer Premier 6 program demo (Premier Biosoft International) and NCBI Primer Blast routine (ncbi.nlm.nih.gov/tools/primer-blast) to select the most appropriate primer pair to be ordered. Primer synthesis was carried out by thermofisher-invitrogen as desalted. Primer sequences and related information are given in Table 1. 


\begin{tabular}{|c|c|c|}
\hline & $\begin{array}{l}\text { BŞEÜ Fen Bilimleri Dergisi } \\
8(2), 636-645,2021\end{array}$ & $\begin{array}{r}\text { BSEU Journal of Science } \\
\text { https://doi.org/10.35193/bseufbd.928182 }\end{array}$ \\
\hline $\begin{array}{l}\text { BilleECIKSEYHEDEBALI } \\
\text { UNIVERSITESI }\end{array}$ & & 2458-7575 (https://dergipark.org.tr/tr/pub/bseufbd) \\
\hline
\end{tabular}

Table 1. Primers used in RT-qPCR studies

\begin{tabular}{|c|c|c|c|c|}
\hline Primer pair & Primer sequences $\left(\mathbf{F} / \mathbf{R}, 5^{\prime} \rightarrow \mathbf{3}^{\prime}\right)$ & $\begin{array}{l}\text { Amplified gene, product } \\
\text { length (bp) }\end{array}$ & $\begin{array}{l}\text { Used annealing } \\
\text { temperature }\left({ }^{\circ} \mathrm{C}\right)\end{array}$ & $\begin{array}{c}\text { Primer } \\
\text { Efficiency }\end{array}$ \\
\hline HKG1 124 & $\begin{array}{l}\text { TTTGACTCAACACGGGGAAA } \\
\text { CAGACAAATCGCTCCACCAA }\end{array}$ & $\begin{array}{l}\text { Zm } 18 \mathrm{~S} \text { rRNA (AF168884.1), } \\
124\end{array}$ & 59 & 1.02 \\
\hline HKG2-2 120 & $\begin{array}{l}\text { TTTAAGGCTGCTGTACTGCTGTAGA } \\
\text { CACTTTCTGCTCATGGTTTAAGG }\end{array}$ & ZmAktin1 (J01238.1), 120 & 59 & 1.02 \\
\hline $\begin{array}{l}\text { TC/TA-A4 } \\
105\end{array}$ & $\begin{array}{l}\text { CTCTCATGACATGCTTATTG } \\
\text { GACATAGACGAAAACATCAG }\end{array}$ & $\begin{array}{l}\text { ZmMPK14 } \\
\text { (GRMZM2G062914), } 105\end{array}$ & 59 & 1.08 \\
\hline
\end{tabular}

RT-qPCRs were carried out with Real Q-Plus 2x Green mix without ROX (Amplicon). Reactions were prepared as $20-\mu 1$ mixtures, containing $10 \mu \mathrm{l}$ Real Q-Plus, 10 picomoles $(1 \mu \mathrm{L})$ of the forward and reverse primers

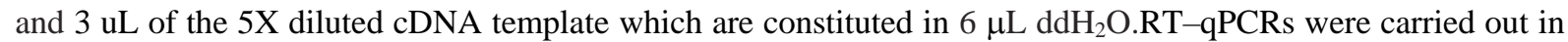
Rotor-Gene Q (Qiagen) Thermal cycler, which was programmed for a HotStart Taq DNA polymerase (TEMPase) activation period of $15 \mathrm{~min}$ at $95^{\circ} \mathrm{C}$, followed by 40 -cycle qPCR with a denaturation of $20 \mathrm{~s}$ at $94{ }^{\circ} \mathrm{C}$, annealing at $59{ }^{\circ} \mathrm{C}$ for $20 \mathrm{~s}$ and extension at $72{ }^{\circ} \mathrm{C}$ for $30 \mathrm{~s}$. Amplification kinetics were monitored at the end of the each extension step via (SYBR) Green fluorescence readings. Maize Actinlwas used as the internal control (reference gene) and for normalization in $P s$ treatment studies whileZm18S rRNA was used as reference gene in chemical treatment experiments. In each run, a reference gene dilution array was employed as standards in Rotor-gene software Cq computations. Relative expression levels were computed manually according to delta-deltaCt method of Livak et. al. [31] using average $\mathrm{Cq}$ values obtained from two technical replications of biological duplicates. All standard statistical computations were carried out with $\mathrm{Cq}$, deltaCq, delta-deltaCq values since they are known to show normal distribution. Comparisons between individual sampling points and control were carried out using $t$ test with delta-deltaCq values. As a last step, mean fold changes and their respective fold change ranges were obtained as $2^{\wedge}$-(delta-deltaCq) and $2^{\wedge}$-(delta-deltaCq \pm Standard Error) respectively.

\section{RESULTS}

ZmMAPK14 similar sequences were identified as the differential expression showing cDNA-AFLP Transcript Derived Fragments (TDFs) in the experiments involving the compatible and incompatible interactions of maize genotypes, A188 and Rpl-G respectively with P. sorghi race T09. Both TDFs were expressed at similar levels in controls of resistant and susceptible genotypes, whereas a gradual induction in the resistant genotype and a clear repression in the susceptible genotype samples were displayed in response to rust inoculations. This pattern of expression was also confirmed partially in sqRT-PCR studies of both genotypes. RT-qPCR studies, on the other hand, revealed a marked induction in response to $P s$ infection in the resistant genotype starting at $6 \mathrm{~h}$ with about 2 -fold, rapidly increasing to 149 folds at $12 \mathrm{~h}$, gradually reaching a expression maxima of 477 -fold at $72 \mathrm{~h}$ (Figure 1a). ZmMAPK14 expression in the Ps infected susceptible genotype with respect to control had an overall twofold induction starting at $6 \mathrm{~h}$ and continuing up to $96 \mathrm{~h}$ of post-inoculation with slight fluctuations, contrary to the initial observation of marked repression upon Ps inoculation in cDNA-AFLP studies and partial repression in RTsqPCRs (Figure 1b). 


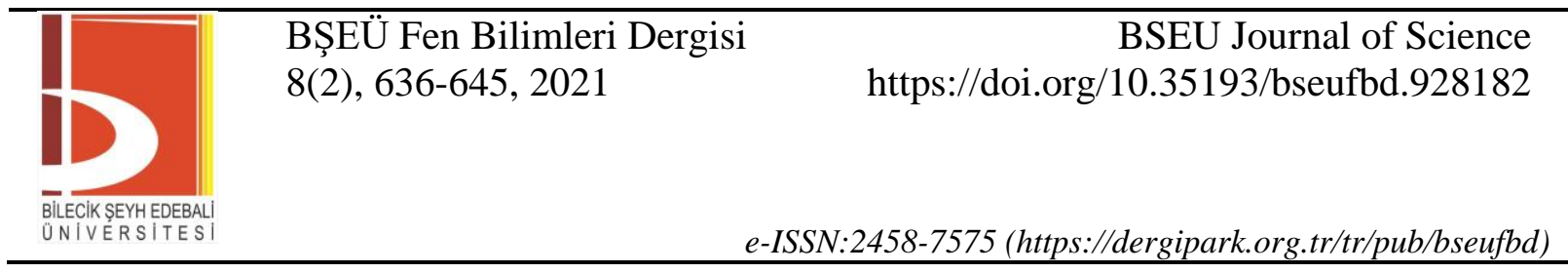

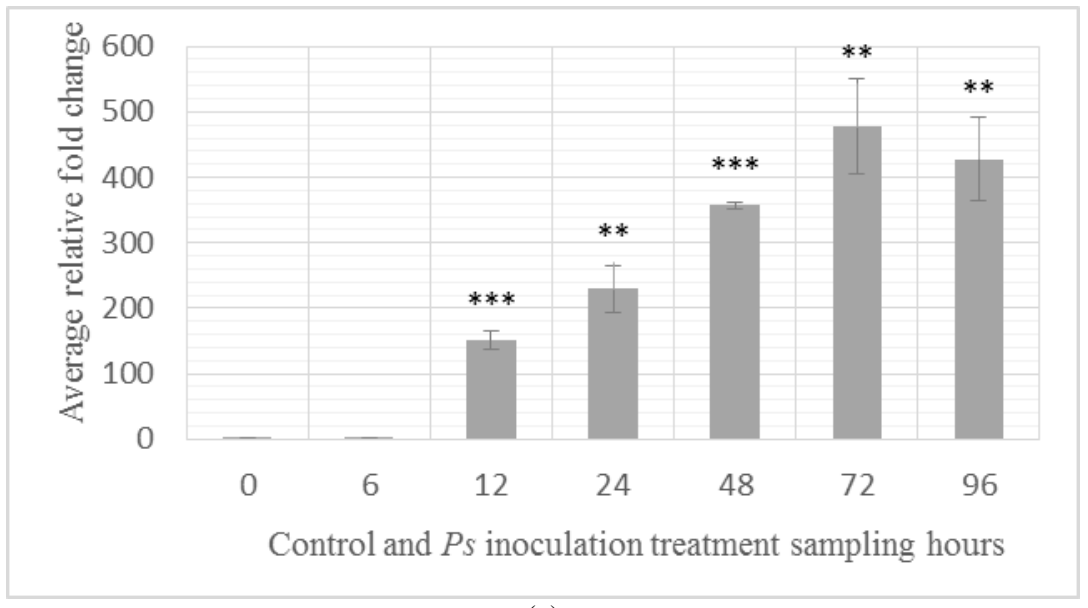

(a)

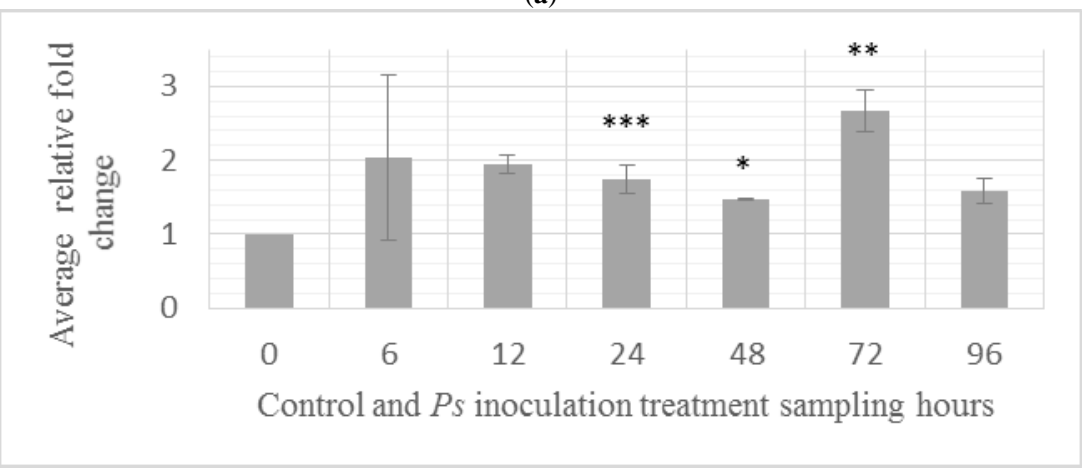

(b)

Figure 1. RT-qPCR assessments of ZmMAPK14 expression change in response to $P s$ inoculation in $R p 1-G$ (a) and A188 (b) leaves. Samples were collected from the control and infected plant leaves as biological duplicates at 0 (control), 6, 12, 24, 48, 72 and $96 \mathrm{~h}$ after $P s$ inoculation. Data were normalized to the expression level of the reference gene and represent (averaged) fold changes with respect to control at each time point. Error bars represent fold change ranges computed from $\Delta \Delta \mathrm{Cq} \pm$ Standard Error. "*” indicates $t$-test $p$-value significance as $*=$ $0.05<p<0.1, * *=0.01<p<0.05, * * *=p<0.01$.

To examine the role of ZmMAPK14 in plant defense, effects of $\mathrm{SA}, \mathrm{H}_{2} \mathrm{O}_{2}$ and chitin applications on ZmMAPK14 expression in both susceptible and resistant genotypes were studied. In the study, applied all treatments induced expressional changes in the resistant genotype samples at different levels and with different profiles. In the resistant genotype, chitin induced expression were significant at $4 \mathrm{~h}$, followed by an over 11-fold at $6 \mathrm{~h}$ and a peak induction of 16 folds at $24 \mathrm{~h}$. SA induced change started at $1 \mathrm{~h}$ with a 7 -fold increase and maintained up to $6 \mathrm{~h}$ sampling point where increase reached over 9-fold and remained at this level. In response to $\mathrm{H}_{2} \mathrm{O}_{2}$ treatment, ZmMAPK14 expression displayed a sharp induction at $1 \mathrm{~h}$ with a 9-fold increase, made a peak at $2 \mathrm{~h}$ with an over 18-fold induction, followed by a gradual decrease to 11 -fold at $6 \mathrm{~h}$ and subsequently making a second peak at $24 \mathrm{~h}$ with a 19 -fold induction (Figure $2 \mathrm{a}$ ). In the susceptible genotype, $\mathrm{H}_{2} \mathrm{O}_{2}$ treatment induced an over 6-fold expression increase at $1 \mathrm{~h}$ similar to resistant genotype followed by relatively lower inductions, 1.5 fold at $2 \mathrm{~h}$ and 3 fold at $4 \mathrm{~h}$ (Figure 2b). Contrary to resistant genotype, SA treatment caused an overall 2-fold induction at $2 \mathrm{~h}$ and $4 \mathrm{~h}$ time points. Chitin treatment produced a 3 -fold induction at both $1 \mathrm{~h}$ and $4 \mathrm{~h}$ time points (Figure 2b). Lower than control level expressions at $1 \mathrm{~h}$ chitin, $4 \mathrm{~h} \mathrm{SA}$ and $6 \mathrm{~h}$ and $24 \mathrm{~h}$ HP treatments were also apparent in the susceptible. 


\begin{tabular}{|c|c|c|}
\hline & $\begin{array}{l}\text { BŞEÜ Fen Bilimleri Dergisi } \\
8(2), 636-645,2021\end{array}$ & $\begin{array}{r}\text { BSEU Journal of Science } \\
\text { https://doi.org/10.35193/bseufbd.928182 }\end{array}$ \\
\hline $\begin{array}{l}\text { BilLECIKSEYHEDEBALI } \\
\text { UNIVERSITESI }\end{array}$ & & 2458-7575 (https://dergipark.org.tr/tr/pub/bseufbd) \\
\hline
\end{tabular}

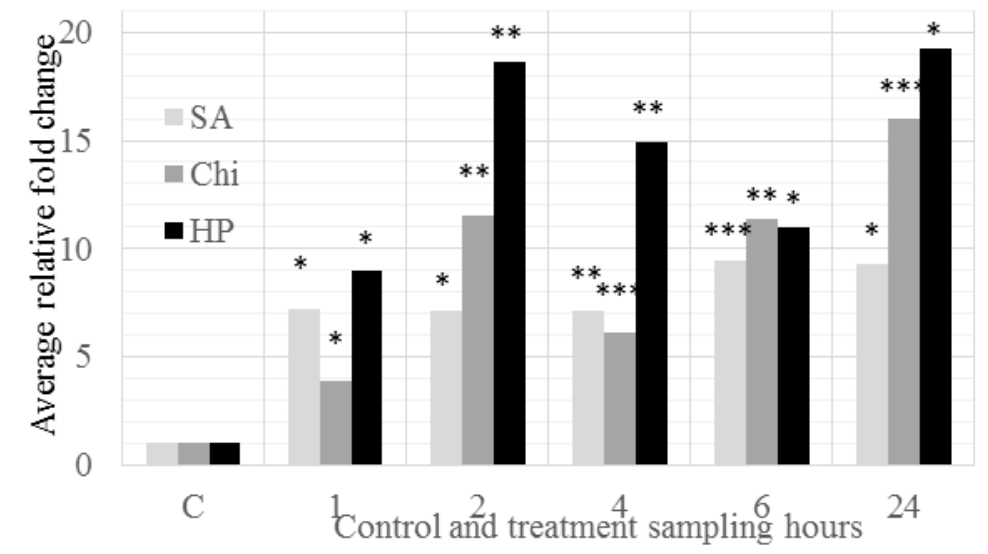

(a)

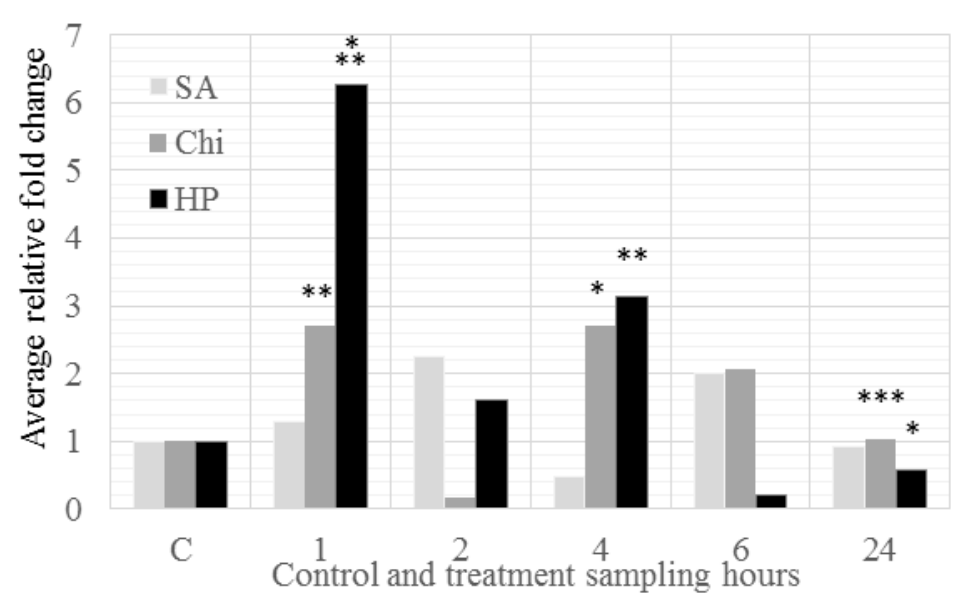

(b)

Figure 2. RT-qPCR assessments of ZmMAPK14 expression changes induced by the applications of $\mathrm{H}_{2} \mathrm{O}_{2}(\mathrm{HP})$, chitin (Chi) and SA treatments in resistant (a) and susceptible (b) genotypes. Samples were collected from the leaves of the control and treatment plants as biological duplicates at $\mathrm{C}$ (control), 1, 2, 4, 6 and $24 \mathrm{~h}$. Graphs were prepared from the normalized expression levels as the relative fold changes with respect to control at each time point. " *" indicates $t$-test $p$-value significance as $*=0.05<p<0.1, * *=0.01<p<0.05, * * *=p<0.01$.

\section{IV.DISCUSSION}

Plant MAPKs appear to be regulated by not only reversible protein phosphorylation/dephosphorylation cycles, but also transcriptional control [24]. Transcriptional regulation of group C plant MAPK genes in response to biotic and abiotic stresses appears to be common. ZmMAPK7, a paralog of ZmMAPK14, is induced in response to exogenous applications of $\mathrm{H}_{2} \mathrm{O}_{2}$ [26]. Reported expression patterns of two ZmMAPKI4 orthologues, $O s M A P K 3 i n$ rice and GhMAPK2 in cotton are also examples of this regulation mode [19,20]. Both were reported to display expressional modulations in response to the phytopathogen/pest infestations as well. OSMAPK3 having 96\% sequence similarity to ZmMAPK14, is expressed marginally in control plants and displayed an upregulation starting at $6 \mathrm{~h}$ continuing with a gradual increase up to 3 days following Nilaparvata lugens infestation. Similarly, Magnaporthe grisea avirulent race inoculation also resulted in a gradual expression increase after inoculation while the virulent race did not promote a noticeable expression change except a slight induction in the $8 \mathrm{~h}$ inoculation sample [19]. Similarly, GhMAPK2, showing 92\% sequence similarity to ZmMAPK14, was reported to be transcriptionally induced in response to Fusarium oxysporum fs vasinfectum inoculation [20]. Initial detection and subsequent RT-qPCR expression validation experiments in the present study showed that ZmMAPK14 mRNA was rapidly induced within an hour of $P$. sorghi inoculation and reached a maximum 477 -fold induction at $72 \mathrm{~h}$ in the incompatible interaction. Expression changes observed in RT-qPCR experiments of the compatible interaction were slight and did not corroborate the repression detected in cDNA-AFLP studies. This differential expression observed between compatible and incompatible interactions closely resembles the expression changes reported for 
OsMAPK3 [19] and OsMAPK4 (another rice group-C MAPK) [32] displayed against the virulent and avirulent races of M. grisea. OSMAPK3 was identified as OmMAPK homolog with a 99\% amino acid identity and suggested to be a disease resistance factor functioning against $N$. lugens and $M$. grisea [19]. With these similarities and observed inductions, ZmMAPK14 suggest itself as a factor, which plays a role in conditioning resistance to phytopathogens. Consistent with this assumption, transgenic tobacco lines overexpressing GhMAPK2, displayed heightened resistance to the tested viruses (TMV, CMV) and fungi (F. oxysporum, P. infestans) infections [21].

Reactive oxygen species (ROS), such as $\mathrm{H}_{2} \mathrm{O}_{2}$, are produced in plants in response to various biotic and abiotic stresses. As a biotic stressor, pathogen challenges induce the synthesis of $\mathrm{H}_{2} \mathrm{O}_{2}$ both transiently in PTI and in a sustained manner in ETI [11,33]. $\mathrm{H}_{2} \mathrm{O}_{2}$ are known to cross biological membranes efficiently and function as both a signaling molecule (seconder messenger) and a defense compound, thereby activating local and systemic defense responses and providing direct protection against invading pathogens to some extent respectively [34]. The role of MAPK signaling in ROS production downstream to MAPK cascades in both PTI and ETI are well known and characterized to some extent [4]. Numerous studies have revealed that $\mathrm{H}_{2} \mathrm{O}_{2}$ activates plant MAPKs [35] and induce expressional changes in MAPK genes, [10,26,27,36-38], however, the mechanism of this transcriptional regulation in plants remains elusive. $\mathrm{H}_{2} \mathrm{O}_{2}$ signal is presumably sensed either by receptors, $\mathrm{ROS}$ sensitive transcription factors like heat shock factors, NPR1 or ROS mediated inhibition of phosphatase, which subsequently turns on a signal transduction pathway, resulting in the orchestration of differential gene expression [39]. $\mathrm{H}_{2} \mathrm{O}_{2}$ induced ZmMAPK14 expression change is evident in both susceptible and resistant genotypes as displayed in Figure 2. Amplitude and profile of induction exhibit obvious differences between them as described before. Promoter identification and a motif search conducted in this study revealed that the putative ZmMAPK14 promoter contains a number of probable ROS-responsive cis-acting elements (ROSE), specifically similar to ROSE7/GCC box reported by Wang et al. [37]. ROSE7/GCC box is the binding site for the Ethylene Responsive element binding Factor 6 (ERF6), which acts as a transcriptional activator of ROS-responsive genes during oxidative stress [37,40]. Accumulating evidence also reveals that ERF6 is an important player and a common component of the ETI triggered by both CNLs (RPS2 and RPM1) and TNLs (RPS4 and RPP4) in conditioning resistance to biotrophic bacterial and oomycete pathogens. ERF6 has been shown to bind and control the expression of several well-known immune regulators, such as MPK3 and WRKY33 [4,41]. A STF1/HY5 binding sequence was also found in the ZmMAPK14 promoter. HY5 transcription factor binds this sequence motif to promote ROS responsive gene expression [42]. Observed ZmMAPK14 expression increase in response to rust inoculation may be due to the endogenous $\mathrm{H}_{2} \mathrm{O}_{2}$ increase triggered by the defense reaction. An experimental ZmMAPK14 promoter analysis should reveal insight about its nature of ROS responsiveness.

Salicylic acid (SA), regarded as a plant defense hormone, is an important endogenous and exogenous signaling molecule, which promotes several local and systemic defense responses especially effective against biotrophs. SA is required for a robust Systemic Acquired Resistance (SAR) induction, and plants defective in SA synthesis and accumulation display increased disease susceptibility [43]. In the present study, spraying $10 \mathrm{mM} \mathrm{SA}$ onto both susceptible and resistant genotype seedling leaves resulted in a marked induction started at $1 \mathrm{~h}$ and maintained with an increase to 9 -fold at $6 \mathrm{~h}$ and $24 \mathrm{~h}$ in the resistant genotype whereas expression increase was limited and complex in the susceptible genotype (Figure 2). SA signal is transmitted via NPR1, a master regulator of SA-dependent defense pathways, by conversion of cytoplasmic NPR1 oligomers to monomers, which are subsequently localized to nucleus where they are phosphorylated and interact with NPR3 and NPR4 in the induction of defense gene expression (e.g. PR genes) in a concentration dependent manner by interacting with transcription factors such as TGAs (basic leucine zipper TFs). NPR1 defective plants are also defective in both SA-induced gene expression and SAR activation [43]. Sun et. al. [10] reported the presence of a SA-responsive TCA-element at ZmMAPK14 promoter, which may be an explanation for the observed SA caused expression change.

Chitin, a polymer of $\mathrm{N}$-acetyl glucosamine, is not found in plants, but a major component of fungal cell walls, which are fragmented during infection to chito-oligosaccharides functioning as elicitor/PAMP. Chitin elicitor binding proteins, CEBiPs and receptor-like kinase, LysM RLK1/CERK1 in Arabidopsis and orthologous in rice and several other species have been identified as membrane proteins functioning in chitin perception and signaling [44]. Plant MAPKs function in chitin defense signaling via either direct activation of MAPKs or expressional modulation $[4,45]$. Chitin induces expressional modulations in a large number of defense-related genes including AtMAPK3 [44]. Regulatory regions of pathogen responsive plant genes contain W-box elements, which are shown to be elicitor responsive [46]. Both Sun et. al. [10] and current study promoter bioinformatics revealed the presence of a fungal elicitor response element, Box-W1 (W-box) in the ZmMAPK14 promoter. Box- 
W1 elements, containing TTGAC $(\mathrm{C} / \mathrm{T})$ sequence motifs, are recognized by WRKY transcription factors, which are known to modulate the expressions of plant defense and defense related genes either directly or indirectly $[11,47,48]$. Consistent with the accumulating knowledge, chitin induced expressional modulation of ZmMAPK14 observed in this study provides clues about its chitin responsiveness and defensive role.

\section{CONCLUSIONS}

Although no direct role, other than expressional change, for its involvement in plant defense has been obtained, the marked expressional induction in the resistant genotype in response to $P s$ inoculation and applications of defense inducing compounds suggest that it plays a direct or indirect role in defense signaling. Expression of GhMAPK2 in transgenics revealed that genotypes display enhanced resistance to the tested fungi and viruses. GhMAPK2 overexpressing transgenics also displayed an increased ability scavenge ROS and tolerate oxidative stress. Based on these findings, a defense signaling role in response to both pathogen infection and oxidative stress has been proposed [21,49]. Further studies similar to that of GhMAPK2 should reveal more insight about the role of ZmMAPK14 in plant defense and related functions.

\section{ACKNOWLEDGEMENTS}

This work was supported by The Council of Turkish Scientific and Technological Research (209T002)

\section{REFRENCES}

[1] Tena, G., Boudsocq, M., \& Sheen, J. (2011). Protein kinase signaling networks in plant innate immunity. Current Opinion in Plant Biology, 14(5), 519-529.

[2] Zhang, M., Su, J., Zhang, Y., Xu. J., \& Zhang, S. (2018). Conveying internal and external signals via MAPKs. Current Opinion in Plant Biology, 45, 1-10.

[3] Taj, G., Agarwal, P., Grant, M., \& Kumar, A. (2010). MAPK machinery in plants Recognition and response to different stresses through multiple signal transduction pathways. Plant Signaling \& Behavior, 5(11), 13701378.

[4] Meng, X., \& Zhang, S. (2013). MAPK cascades in plant disease resistance signaling. Annual Review of Phytopathology, 51, 245-266.

[5] Kong, X., Lv, W., Zhang, S., Jiang, S., \& Li, D. (2013). Genome-wide identification and analysis of expression profiles of maize mitogen-activated protein kinase kinase kinase, PLoS ONE, 8 e57714.

[6] Kong, X., Pan, J., Zhang, D., Jiang, S., Cai, G., Wang, L., \& Li, D. (2013). Identification of mitogen-activated protein kinase kinase gene family and MKK-MAPK interaction network in maize. Biochemical and Biophysical Research Communications, 441, 964-969.

[7] Wei, K., Wang, Y., Zhong, X., \& Pan, S. (2014). Protein kinase structure, expression and regulation in maize drought signalling. Molecular Breeding 34, 583-602.

[8] Liu, Y., Zhang, D., Wang, L., \& Li, D. (2013). Genome-Wide Analysis of Mitogen-Activated Protein Kinase Gene Family in Maize. Plant Molecular Biology Reporter, 31, 1446-1460.

[9] Mohanta, T. K., Arora, P. K., Mohanta, N., Parida, P., \& Bae, H. (2015). Identification of new members of the MAPK gene family in plants shows diverse conserved domains and novel activation loop variants. BMC Genomics, 16:58, 1-20.

[10] Sun, W., Chen, H., Wang, J., Sun, H. W., Yang, S. K., Sang, Y. L., Lu, X. B., \& Xu, X. H. (2015). Expression analysis of genes encoding mitogen-activated protein kinases in maize provides a key link between abiotic stress signaling and plant reproduction" Functional and Integrative Genomics, 15, 107-120.

[11] Adachi, H., Nakano, T., Miyagawa, N., Ishihama, N., Yoshioka, M., Katou, Y., Yaeno, T., Shirasu, K., \& Yoshioka, H. (2015). WRKY Transcription Factors Phosphorylated by MAPK Regulate a Plant Immune NADPH Oxidase in. Nicotiana benthamiana. The Plant Cell, 27, 2645-2663.

[12] Cheng, Z., Li, J. F., Niu, Y., Zhang, X. C., Woody, O. Z., Xiong, Y., Djonovic, S., Miller, Y., Bush, J., McConkey, J. B., Sheen, J., \& Ausubel, F. M. (2015). Pathogen-secreted proteases activate a novel plant immune pathway. Nature, 521, 213-216.

[13] Devendrakumar, K. H., Li, X., \& Zhang, Y. (2018). MAP Kinase signaling: interplays between plant and effector-triggered immunity. Cellular and Molecular Life Sciences, 75, 2981-2989.

[14] Tsuda, K., Mine, A., Bethke, G., Igarashi, D., Botanga, C. J., Tsuda, Y., Glazebrook, J., Sato, M., \& Katagiri, F. (2013). Dual regulation of gene expression mediated by extended MAPK activation and salicylic acid contributes to robust innate immunity in Arabidopsis thaliana. PLoS Genetics 9, e1004015.

[15] Bigeard, J., Colcombet, J., \& Hirt, H. (2015). Signaling Mechanisms in Pattern-Triggered Immunity (PTI). Molecular Plant, 8, 521-539. 
[16] Bi, G., \& Zhou, J. (2017). MAP Kinase signaling pathways: A hub of plant-microbe interactions. Cell Host \&Microbe, 27, 270-273.

[17] Xiang, T., Zong, N., Zou, Y., Wu, Y., Zhang, J., Xing, W., Li, Y., Tang, X., Zhu, L., Chai, J., \& Zhou, J. M. (2008). Pseudomonas syringae effector AvrPto blocks innate immunity by targeting receptor kinases. Current Biology, 18, 74-80.

[18] Yamaguchi, K., Yamada, K., Kazuya, I. K., Yoshimura, S., Hayashi, N., Uchihashi, K., Ishihama, N., KishiKaboshi, M., Takahashi, A., \& Tsuge, S.. et. al. (2013). A receptor-like cytoplasmic kinase targeted by a plant pathogen effector is directly phosphorylated by the chitin receptor and mediates rice immunity. Cell Host \& Microbe, 13, 347-357.

[19] Shin, H. Y., You, M. K., Jeung, J. U., \& Shin, J. S. (2014).OsMPK3 is a TEY-type rice MAPK in group C and phosphorylates OsbHLH65, a transcription factor binding to E-box. Plant Cell Rep. 33, 1343-1353.

[20] Wang, M., Zhang, Y., Wang, J., Wu, X., \& Guo, X. (2007). A novel MAP kinase gene in cotton (Gossypium hirsutum L.), GhMAPK, is involved in response to diverse environmental stresses. Journal of Biochemistry and Molecular Biology, 40, 325-332.

[21] Zhang, L., Dongmei, X., Luo, L., Meng, F., Li, Y., Wu, C., \& Guo, X. (2011). Cotton GhMPK2 is involved in multiple signaling pathways and mediates defense responses to pathogen infection and oxidative stress. FEBS Journal, 278, 1367-1378.

[22] Sun, T., Nitta, Y., Zhang, Q., Wu, D., Tian, H., Lee, J. S., \& Zhang, Y. (2018). Antagonistic interactions between two MAP kinase cascades in plant development and immune signaling. EMBO reports, 19, e45324.

[23] Gao, M., Liu, J., Bi, D., Zhang, Z., Cheng, F., Chen, S., \& Zhang, Y. (2008). MEKK1, MKK1/MKK2 and MPK4 function together in a mitogen- activated protein kinase cascade to regulate innate immunity in plants. Cell Res, 18(12), 1190-1198.

[24] Hirt, H. (1999). Transcriptional upregulation of signaling pathways: more complex than anticipated? Trends Plant Science, 4, 7-8.

[25] Seo, S., Okamoto, M., Seto, H., Ishizuka, K., Sano, H., \& Ohashi, Y. (1995). Tobacco MAP kinase: a possible mediator in wound signal transduction pathways. Science, 270, 1988-1992.

[26] Wu, J., Hettenhausen, C., Meldau, S., \& Baldwin, I. T. (2007). Herbivory rapidly activates MAPK signaling in attacked and unattacked leaf regions but not between leaves of Nicotiana attenuata. Plant Cell, 19, 10961122.

[27] Zong, X., Li, D., Gu, L., Li, D., Liu, L., \& Hu, X. (2009). Abscisic acid and hydrogen peroxide induce a novel maize group C MAP kinase gene, ZmMPK7, which is responsible for the removal of reactive oxygen species. Planta, 229, 485-495.

[28] Pan, J., Zhang, M., Kong, X., Xing, X., Liu, Y., Zhou, Y., Liu, Y., Sun, L., \& Li, D. (2012) ZmMPK17, a novel maize group D MAP kinase, is involved in multiple stress responses. Planta, 235, 661-676.

[29] Zhang, B., Ramonell, K., Someville, S., \& Stacey, G. (2002). Characterization of early, chitin-induced gene expression in Arabidopsis. Molecular Plant Microbe Interactions, 15, 963-970.

[30] Südüpak, M. A. (2014). A cDNA-AFLP protocol with reciprocally arranged 2-enzyme sequential digestion and silver staining detection. Turkish Journal of Biology, 38, 260-270.

[31] Livak, K. J.\& Schmittgen, T. D. (2001). Analysis of relative gene expression data using real-time quantitative PCR and the $2^{-\Delta \Delta C T}$ method. Methods, 25, 402-408.

[32] Reyna, N. S. \& Yang, Y. (2006). Molecular analysis of the rice MAP Kinase gene family in relation to Magnaporthe grisea infection. Molecular Plant Microbe Interactions, 19, 530-540.

[33] Mur, L. A,, Kenton, P., Loyd, A. J., Ougham, H., \& Prats, E. (2008). The hypersensitive response; the centenary is upon us but how much do we know? J. Experimental Botany, 59, 501-520.

[34] Shetty, N. P., Jørgensen, H. J. L., Jensen, J. D., Collinge, D. B., \& Shetty, H. S. (2008). Roles of reactive oxygen species in interactions between plants and pathogens. European Journal Plant Pathology, 121, 267280.

[35] Liu, Y. \& He, C. (2017). A review of redox signaling and the control of MAP kinase pathway in plants. Plant Redox Biology, 11, 192-204.

[36] Zhang, S., \& Klessig, D. F.(2001). MAPK cascades in plant defense signaling. Trends in Plant Science 6(11), 520-527.

[37] Zhang, J., Shao, F., Li, Y., Cui, H., Chen, L., Li, H., Zou, Y., Long, C.,Lan, L., Chai, J., Chen, S., Tang, X., \& Zhou, J. M. (2007). A Pseudomonas syringe Effector inactivates MAPKs to supress PAMP-induced immunity in plants. Cell Host \&Microbe, 1, 175-185.

[38] Wang, J., Ding, H., Zhang, A., Ma, F., Cao, J., \& Jiang, M. (2010). A novel MAPK, MAPK3, is involved in response to diverse environmental cues. Journal of Integrative. Plant Biology, 52, 442-452. 
[39] Jalmi, S. K., \& Sinha, A. K. (2015). ROS mediated MAPK signaling in abiotic and biotic stress- striking similarities and differences. Frontiers in Plant Science 6, 769.

[40] Sewelam, N., Kazan, K., Thomas-Hall, S. R., Kidd, B. N., Manners, J. M., \& Schenk, P. M. (2013). Ethylene Response Factor 6 Is a Regulator of Reactive Oxygen Species Signaling in Arabidopsis. PLoS ONE 8(8), e70289.

[41] Mine, A., Seyfferth, C., Kracher, B., Berens, M. L., Becker, D., \& Tsuda, K. (2018). The defense phytohormone signaling network enables rapid, high-amplitude transcriptional reprogramming during effector-triggered immunity. The Plant Cell, 30, 1199-1219.

[42] Gangappa, S. N., \& Botto, J. F. (2016). The Multifaceted Roles of HY5 in plant growth and development. Mol. Plant, 9, 1353-1365.

[43] Kumar, D. (2014). Salicylic acid signaling in disease resistance. Plant Science, 228, 127-134.

[44] Wan, J., Zhang, X. C., Neece, D., Ramonell, K. M., Clough, S., Kim, S. Y., Stacey, M. G., \& Stacey, G. (2008). A LysM receptor-like kinase plays a critical role in chitin signaling and fungal resistance in Arabidopsis. Plant Cell, 20, 471-481.

[45] Wan, J., Zhang, S., \& Stacey, G. (2004). Activation of a mitogen-activated protein kinase pathway in Arabidopsis by chitin. Molecular Plant. Pathology, 5, 125-135.

[46] Rushton, P. J., \& Somssich, I. E. (1998). Transcriptional control of plant genes responsive to pathogens. Current Opinion in Plant Biology, 1, 311-315.

[47] Eulgem, T, Rushton, P. J., Robatzek, S., \& Somssich, I. E. (2000). The WRKY superfamily of plant transcription factors. Trends Plant Science, 5, 199-206.

[48] Ülker, B., \& Somssich, I.E.(2004). WRKY transcription factors: from DNA binding towards biological function. Current Opinion in Plant Biology, 7, 491-498.

[49] Zhang, L., Dongmei, X., Li, S., Gao, Z., Zhao, S., Shi, J., Wu, C., \& Guo, X. (2011). A cotton group C MAP kinase gene, GhMPK2, positively regulates salt and drought tolerance in tobacco. Plant Molecular Biology, 77, 17-31. 